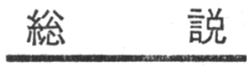

\title{
混ぜる—分散と溶解
}

\author{
荻 野 圭 三 \\ 東京理科大学理工学部 (野田市山崎 2641) \\ 東京理科大学界面科学研究所 (東京都新宿区神楽坂 1-3)
}

\section{Dispersion and Dissolution}

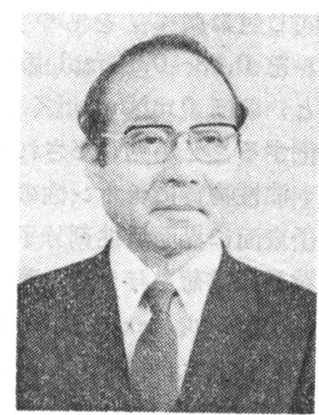

\section{Keizo Ogino}

Faculty of Science and Technology, Science University of Tokyo (2641, Yamazaki, Noda-shi, Chiba)

Institute of Colloid and Interface Science University of Tokyo

(1-3, Kagurazaka, Shinjuku-ku, Tokyo)

\section{はじめに}

いわゆる “添加剤” は補助的な役割を果たしているが， それを加えることによって性能, 機能が格段と向上し, これなくしては製品になり得ないものが多い。その意味 では配合量は比較的少なくても不可欠の成分ということ ができる。さて，著者に与えられた “分散と溶解”とい うことを添加剤といら面からとらえるとすれば, 分散 剤, 溶解剤ということになり, 著者の専門から界面活性 剤を主体とせざるを得ない, となれば, 対象は分散につ いては, エマルション, サスペンションが, 溶解につい ては可溶化が中心となる。しかし, 界面活性剤の種類の 多いこと, 広範囲の応用分野についてすべて網羅するこ とは到底不可能である。そこで, 便宜上いくつかに分 け，また偏った例をあげて書きつつうってみたが決して満 足いくものではないが，いくらかでも読者のお役に立て ば幸いである。

\section{1 分 散}

\section{$1 \cdot 1$ 液/夜分散系}

水と油とは互いに混じり合わないが,このいずれか一 方を微細な粒子にして他方の連続相に均一に分散するこ とによって, O/W 型及び W/O 型エマルションが生成 する。エマルションは化粧品, 食品, 塗料, インキ, 農 薬, 乳化重合等, 広く用いられ, 工業的に極めて 重要 である。しかし, エマルションは熱力学的には不安定 で, 均一で安定なエマルションを得るためには有効な分 散剤が必要となる。

\section{$1 \cdot 1 \cdot 1$ 水系エマルション}

まず, 水系エマルション, すなわち O/W 型エマルシ ヨンを生成する場合, 連続相の水に対し分散相の油には
無極性油のほか, 極性の異なる種々の油が用いられる。 このうち, 無極性油は水と混じり合わず最もエマルショ ンにしにくい油である。

一般に, エマルションを生成させるには, 物理化学的 には, 油/水界面に各種の界面活性物質を吸着させて界 面張力を低下させ, 一たん生成した油粒子が，クリーミ ング, 凝集及び合一を起こして分離しないようにしてや ることが重要である11。

無極性の Nujol をアニオン界面活性剤で乳化するこ とは難しい。それはイオン性界面活性剤の水溶性が大き すぎるためである。このような場合, Nujol に極性を有 する乳化助剂, たとえば, 脂肪酸, 脂肪族アルコール及 びコレステロール等を少量添加してやると有効である。

Fig.-1 に, 添加する極性油性物質の種類をかえて Nujol と水との界面張力を測定した結果を示してあるが，コレ ステロールの効果が顕著なことが見いだされる2゙。また，

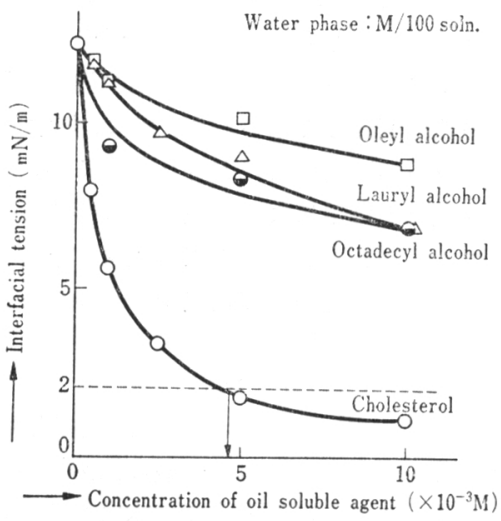

Fig.-1 Effect of oil soluble agent on the interfacial tension at Nujol/SDS soln. interface. 
同じ炭素数 $\mathrm{C}_{12}$ をむつ無極性ドデカン中にドデカノー ルを $0.03 \sim 0.10 \mathrm{~mol}$ 添加し, SDS 溶液と接触させる と, ほぼ $0 \mathrm{mN} / \mathrm{m}$ 近くまで界面張力が低下し, 自然乳 化することが見いだされている3)。

油性物質にイオン性の界面活性剤が吸着すると, 油粒 子表面に界面活性剤分子の親油基をむけて配向吸着し, 粒子に電荷を与える。著者らも, 極性油のオレイン酸や オイルアルコールが SDS 溶液中で ら-電位が著しく増 加することを見いだしている4。

無極性油の乳化に関しては, イオン性界面活性剤より 非イオン性器面活性剤の方が有効にはたらくが，それで も乳化助剤の効果は大きい。たとえば，無極性 Nujol 中 に前述の脂肪酸, 高級アルコール, コレステロール等の 極性物質を添加してやることにより界面張力が著しく低 下し自然乳化をおこすに至る。この場合もコレステロー ルの効果は著しい5。

非イオン界面活性剈を用いて得られるエマルション粒 子荷電をもたず, 水和されたエチレンオキシド鎖が油 粒子表面を覆い，立体保護作用によって合一が防がれ る。したがって, HLB 值からみると, O/W 型エマル ションでは高い HLB 值のものが好ましく, ポリオキ シエチレン型非イオン界面活性剤では, オキシエチレ ン鎖の長い方が合一がおこりにくいことが知られてい $る^{6\rangle, 7)}$ 。またオキシエチレン鎖の付加モル数分布に関し ても, 分布のある市販品がよいとされ ${ }^{8)}$, さらに, アル キル鎖長についても異なる鎖長を含むものが有効である といわれるき。

一方, エマルションの作成方法によっても, 非イオン 界面活性剂の HLB が温度によって变化することを利 用した転相温度乳化法 ${ }^{102,11)}$, ゲル乳化法 ${ }^{12)}$, さらにD 相乳化法 ${ }^{13}$ 等が開発され, 均質で細かい安定な乳化滴が 得られることが報告されている。さらに，添加剤として の co-surfactant として多価アルコールが用いられるこ ともあり ${ }^{14)}$ ，また，1,3-ブタンジオール等の 2 価アルコ 一ルが有効であることも知られている ${ }^{14), 15) 。 ~}$

ポリビニルアルコール (PVA) も植物油, 鉱油, ワッ クスなどの乳化剂として用いられ, 特に, 加水分解度 76 〜79\% の中・高粘度用がよいとされているが,さらに,他 の界面活性剂との併用によって乳化効果があがる(16),17)。

特殊エマルションとして, 人工血液素材を含フッ素系 非イオン界面活性剤它用いて安定なエマルションとする ことも報告されている礼。

$1 \cdot 1 \cdot 2$ 非水系エマルション

非水系エマルション,すなわち油を連続相とする W/O 型エマルションをつくるには, 一般に油溶性界面活性剂 が用いられる。これらは形の上では水溶性のものと同じ であるが，イオン性たとえばアニオン界面活性剤では, 水溶性が高すぎるため, 酸の形か, あるいは通常, 金属
塩 $(\mathrm{Ca}, \mathrm{Mg}, \mathrm{Ba}$ ) など疎水性にしたものが用いられる。 また, 非イオン系界面活性剤では, HLB の小さいもの が有効である。

無極性油のアニオン界面活性剤による W/O 型エマル ションの作成には酸型特に硫酸塩, スルホン酸塩などの ものが有効であるが，目的によっては使えないので，こ こでも脂肪酸や高級アルコールなどの極性油性物質を添 加してやる。実用的なの決非イオン界面活性剤によるエ マルションで, 化粧品, 食品をはじめ多くの用途が開け ている。

非イオン界面活性剤を用いてつくられる W/O 型エマ ルションは粒子間に静電的な反発がないため, O/W エ マルションに比較して凝集がおこりやすく, 見かけ上ク リーミングとなって分離してくる。また, HLB の小さ い非イオン界面活性片は, 一般に油相に溶け込みやす く, 界面吸着量が減るため, エマルション粒子の合一が 起こりやすい。このため糖類やアミノ酸等の助剤の添加 が有効とされている(19,20)。

䉆谷 ${ }^{21), 22)}$ は, 非イオン界面活性剤を用いて W/O 型エ マルションをつくるための最適乳化剤の選択法を見つけ 出している。これによると, 与えられた系に対してまず 乳化剂として $\mathrm{R}_{9} \mathrm{C}_{6} \mathrm{H}_{4} \mathrm{O}(\mathrm{EO}){ }_{n} \mathrm{H}$ の適当な鎖長のものを 用いて転相温度を求め, 乳化系を保存しようとする温度 を転相温度とする $n$ の值を求め, その $n$ の值より 2 だけ小さいもの $(0.70 \sim 0.88$ を掛けた值)をもつもの が最邉乳化剂になるとしている。Fig.-2 にシクロへキ サン一水系における種々の非イオン界面活性剤の転相温 度と $n$ の值との関係を示す。そして, 流動パラフィン/ 水系では $\mathrm{R}_{9} \mathrm{C}_{8} \mathrm{H}_{4} \mathrm{O}\left(\mathrm{C}_{2} \mathrm{H}_{4} \mathrm{O}\right)_{3.2-4.1} \mathrm{H}$, シクロヘキサン/水 系では $\mathrm{R}_{9} \mathrm{C}_{6} \mathrm{H}_{4} \mathrm{O}\left(\mathrm{C}_{2} \mathrm{H}_{4} \mathrm{O}\right)_{4.3-5.6} \mathrm{H}$ が, $25^{\circ} \mathrm{C}$ で最適であ

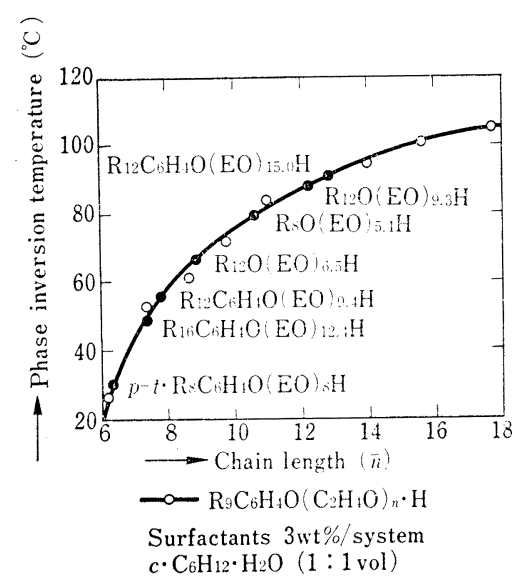

Fig. -2 The $\bar{n}$ number of polyoxyethylene $(\bar{n})$ nonylphenyl ether corresponding to the PIT of some nonionic surfactants. 
ることを見いだしている。

また,オキシエチレン鎖の少ない非イオン界面活性剤 中には未付加の親油基がかなり残存し, 合一安定性に悪 影響を及ぼす。安定な $\mathrm{W} / \mathrm{O}$ 型エマルションを得るには， オキシエチレン鎖の分布は適当にあった方がよいが，市 まり長鎖のオキシエチレン付加体を含むのはよくない。 一方, 親油基については, アルキル鎖長が大きい方が, エマルションの安定性は向上するが，あまり長すぎると 界面活性剂が固化析出し, エマルションの分離がおこ る。これを防ぐには，アルキル基を分枝させた方が良い ことが提案されている ${ }^{23)}$ 。

\section{$1 \cdot 2$ 固/液分散系}

顔料, 粉体などの固体微粒子を液体中に安定に分散さ せてサスペンションを得ることは, 塗料, 化粧品, 農薬 等において極めて重要である。そして,これらを得るた めに添加剤として界面活性剤や高分子物質等の分散剤が 必要となる。これら 分散剤は固体粒子/液体界面に吸着 し, 粒子間の凝集を防止する。この作用は固体微粒子, 分散剂及び溶剂（媒）との親和性が大きな要因となる。 すなわち，粒子自体が親媒性であるか疎媒性であるかに よって分散剤の作用機構も異なってくる。

$1 \cdot 2 \cdot 1$ 水系サスペンション

a) 極性表面をもつ粒子の分散

i）表面電荷の付加による。帯電したコロイド粒子は 表面電荷により電気二重層を形成し, 反発力によって分 散すること注 DLVO 理論 ${ }^{24)}$,25) によって定量的に取り 扱いがなされている。この場合, 表面電荷をより大きく してやること注安定なサスペンションを得るのに有効で ある。

一般に, $\mathrm{CaCl}_{2}, \mathrm{BaSO}_{4}$ 等の無機塩の $\zeta$-電位は $\mathrm{pH}$ に よってあまり変化しないが, $\mathrm{Al}_{2} \mathrm{O}_{3}, \mathrm{SiO}_{2} \mathrm{TiO}_{2}$ 等の無 機酸化物の ら-電位は $\mathrm{pH}$ によって大きく変化する。た とえば, アルミナゾルでは低い $\mathrm{pH} て ゙, \mathrm{Al}^{3+}$ の吸着に より正に荷電し，高い $\mathrm{pH}$ では $\mathrm{OH}^{-}$または $\mathrm{AlO}_{2}^{-}$-の 吸着により負に荷電することはよく知られている ${ }^{26) 。 ま ~}$ た，カオリン，粘土鉱物の $\zeta$-電位は $\mathrm{pH}$ が低いと $\mathrm{H}^{+}$ を吸着して不安定になり凝集がおこるが $\mathrm{pH} 7$ 以上で安

Table-1 Electrophoresis data on dilute sodium kaolin suspensions, $\mathrm{pH}=7.0$

\begin{tabular}{l|c|l}
\hline \multicolumn{1}{c|}{ Deflocculant added } & $\begin{array}{c}\text { Measured zeta } \\
\text { potential }(\mathrm{mV})\end{array}$ & $\begin{array}{c}\text { Appearance of clay in } \\
\text { microscope }(120 \times)\end{array}$ \\
\hline None & -71 & Flocs in clear liquid \\
Sodium chloride & -72 & As above \\
Sodium orthophosphate & -109 & Some small flocs \\
Sodium trimetaphosphate & -93 & Manyvery small flocs \\
Sodium pyrophosphate & -114 & Some very fine flocs \\
Class : $7 \mathrm{Na}_{2} \mathrm{O} / 5 \mathrm{P}_{2} \mathrm{O}_{3}(\mathrm{R}=5)$ & -130 & Unresolved milky liquid \\
Class : $\mathrm{Na}_{2} \mathrm{O} / \mathrm{P}_{2} \mathrm{O}_{3}(\mathrm{R}=200)$ & -135 & As preceding sample \\
\hline
\end{tabular}

a (5.0 milliatomic weights of phosphorus) per $100 \mathrm{~g}$. dry clay.
定なコロイド性を示す。さらに，ポリリン酸塩などを添 加することにより粒子の負のら-電位は向上し, Table-1 に見られるような安定なサスペンションが得られる27)。

ii）界面活性鼡の吸着による。一般に, 水系で極性 またはイオン性表面をもつ微粉体に, イオン性界面活性 鼡を添加すると，極性基間相互作用あるいはイオン間相 互作用によって，まず Fig.-3(a) のように単分子吸着 し,ついで界面活性剤濃度が高くなるにつれ, 界面活性 剤の疎水基同士の結合によって第二層を形成し，固体微 粒子が水中に分散される $[(\mathbf{b})]$ 。この場合, 粒子雪荷と 反対のイオン性界面活性剂を用いた場合には, 電荷の逆 転がおこる ${ }^{26)}$ 。(a) の単分子吸着に関しては, 同じ親水 基の界面活性剂を用いた場合, アルキル鎖長が大きくな るにつれ飽和吸着量に達する平衡濃度が小さくなり，い わゆる Traube 則 ${ }^{28)}$ が適用され, 低濃度で効果を発揮 するが，あまり大きくなると Krafft 点が高くなり常温 で使えなくなる。これを防ぐには分枝アルキル鎖のもの が有効である。また，(b) の第二層の吸着分子は非イオ ン界面活性剤によって置きかえることができ，その方が 安定なものが得られる場合がある。

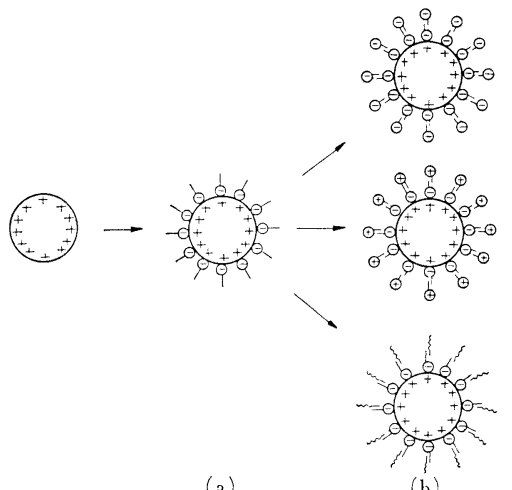

(a)

(b)

Fig.-3 Double adsorption layer of surfactant on solid particles.

b）非極性（疎水性）表面をもつ粒子の分散

i）界面活性剂の吸着による。カーボンブラックやグ ラファイトは製造方法によって極くわずかの含酸素表面 官能基が存在するが299，一般には疎水性の炭素表面をも っている。したがって, これらを水中に分散 するには界面活性剤が有効で, イオン性, 非 イオン性いずれの界面活性凨でも可能であ る。この場合, 界面活性戍分子は炭化水素鎖 を疎水結合によって炭素粒子表面に, 親水基 を水にむけて配向吸着し，イオン性の場合に は電荷を与え, 非イオン性界面活性剂では立 体保護作用によって粒子を分散させる。SDS の場合, $5 \times 10^{-4} \mathrm{M}$ で充分安定なカーボンブ ラックのサスペンションが得られる。イオン 性界面活性剂の場合, 吸着等温線にしばしば 


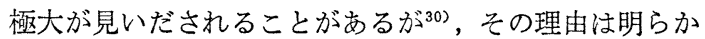
でない。グラファイト粒子表面への SDS, ポリオキシ エチレン系非イオン界面活性剤の吸着は Langmuir 型 であることが認められている ${ }^{31), 82) 。 ~}$

ii）オリゴソープによる 上述の界面活性剤による 分散系は, 共存イオン, $\mathrm{pH}$, 温度等の影響を受け, 不安 定になる場合があり, また, 塗料における顔料の分散に おいて塗膜の耐水性が劣るなどの欠点がしばしばおこ る。また, 最近は公害対策と省資源の面から油性塗料の 水性化 ${ }^{33)}$ 重要になりつつある。そこで, このような欠 点の少ない重合体型分散剤が使用されつつある。たとえ ば,ナフタレンスルホン酸ナトリウム・ホルマリン縮合 物 ${ }^{34)}$,35), スチレン・マレイン酸共重合体 ${ }^{35)}$, 及びポリア クリル酸ナトリウムとその誘導体 ${ }^{36)}$ などの顔料に対する 分散作用が報告されている。

最近は, 低重合度の重合体型界面活性凧（オリゴソー プ）として, マレイン酸誘導体をアルキルビニルエーテ ルとの交互共低重合 体汁儿化物 ${ }^{37}$ （式一 1)，アクリル酸とア クリロニトリルとか らなる共重合体型才 リゴマー38) (式-2) などが,フタロシア ニンやカーボンブラ ックなど難分散性の $\left[\begin{array}{ccc}-\mathrm{CH}-\mathrm{CH}_{2}-\mathrm{CH}-\mathrm{CH}- \\ 1 & \mathrm{CO} & \mathrm{CO} \\ \mathrm{O} & \vdots & \vdots \\ \mathrm{R} & \mathrm{O} & 0 \\ \multicolumn{4}{c}{(\mathrm{Y}-1)} & \mathrm{Y}\end{array}\right]_{n}$

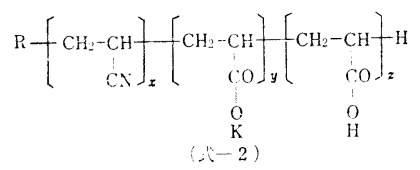
顔料粒子の分散に効果があることが認められている。

これらのオリゴソープは, $0.01 \%$ の低濃度でもアニ オン界面活性剤より大きな分散力を示す。これは疎水性 表面粒子にオリゴソープの疎水部が van der Waals 力 によって吸着し, かさ高い構造と分散に対して有効な多 官能 (多数の側鎖アルキル基, カルボキシラート及びエ ステル基）による立体保護効果が重要な役割を果たし, また，オリゴソープの顔料に対する湿潤作用の向上によ る効果も与えられる。

$1 \cdot 2 \cdot 2$ 非水系サスペンション

工業的に重要な非水系の 固/液分散系は, 主に塗料, 油性インキ, また最近では COM, メタコールなどが関 連する。この場合も, 分散剂として界面活性剤ならびに 高分子物質が用いられるが，固体粒子 (顔料)，分散剂， 溶剤間の相互作用が重要となり, それぞれの親和性が大 きく影響する。

a）界面活性剤による分散

固体粒子を非水溶媒に分散させるに位子表面が極 性, 非極性にかかわらず溶媒にぬれやすくすることが必 要である。そのため界面活性剤処理が行われるが，この 場合, W/O エマルションの項で述べたように, 非水系 では水系ほど粒子に荷電を与えて安定化をはかることは
期待できない。イオン性界面活性剤では金属セッケンが 古くから用いられており, 特に極性表面をもつ粒子に効 果的である。また，1,2-ビス（2-エチルヘキシルオキシ カルボニル)-1-エタンスルホン酸ナトリウム (AerosolOT) はすぐれた分散効果を示すことが知られている ${ }^{399}$ 。

非水系溶媒から疎水性, 親水性粒子表面一の界面活性 剤の吸着モデルは Fig.-4のように示され, 粒子表面が カーボンブラック等の疎水性表面の場合, シクロヘキサ ンのような溶媒中で非イオン界面活性荗を粒子表面につ け，また，極性表面をもつ粒子表面にも同椂の溶媒中で， 粒子表面を疎水化して非水系溶媒に始れすくしてや ることができる ${ }^{40)}$ 。また, 非水系の特殊な顔料分散剤の 一つとして銅フタロシアニン誘導体 $\mathrm{CPC}-\left(\mathrm{CH}_{2} \mathrm{~N}<\mathrm{R}_{2}\right)_{n}$ $\left(\mathrm{R}_{1}: \mathrm{H}\right.$ またはアルキル基, $\mathrm{R}_{2}$ : アルキル基, $\mathrm{CPC}:$ 銅 フタロシアニン基) ${ }^{41)}$ の効果が認められている41)。
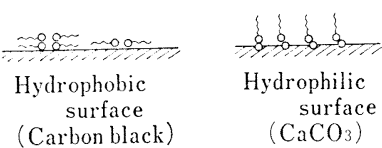

Fig.-4 Adsorption model of surfactants on the surfaces of hydrophobic and hydrophilic solid from non-aqueous solvents.

b）高分子分散剂による分散

非水系塗料における顔料分散安定化をはかるには, 顔 料, 樹脂, 溶剂間の相互作用をどのように取り扱ったら よいか問題になるが，この三者間にはそれぞれいろいろ な種類が存在し, 古くから，いろいろな試みがなされて いるがあまり有効な方法はなく, 経験によるところが多 W。

藤谷ら ${ }^{42)}$ は, いくつかの顔料と溶剤とをとりあげ, 顔 料に対する溶剤の付着張力と溶剤の溶解度パラメーター との関連について，次の事実を明らかにしている。すな わち, 付着張力 (A) と Hansen の水素結合性溶解度パ ラメーター $\delta_{h}{ }^{43)}$ との間に注関係がみられ，A- $\delta_{h}$ スぺ クトルより使用した顔料を Fig.-5 に示すように三つの グループに分類している。そして, Aタイプに属し, 小さ い $\delta_{h}$ の溶剤で付着張力が最大となる顔料 (例, $\mathrm{TiO}_{2}$ ) はマレイン酸樹脂溶液中で 容易に分散し， $\delta_{h}$ が大きい 溶剤で付着張力が最大となる顔料はブチル化メラミン樹 脂溶液中で容易に分散する。Cタイプに属する顔料（例 カーボンブラック, フタロシアニンブルー等）はいずれ の樹脂溶液中でも容易に分散し, また, B タイプの顔 料（例, Insoluble Azo B) はいずれの樹脂溶液中でも 分散しにくいことを認めている。

\section{3 固/固分散系}

代表的な固/固分散系としてはプラスチックの複合化 があげられる。すなおち, 熱硬化性樹脂系複合材料 FRP 


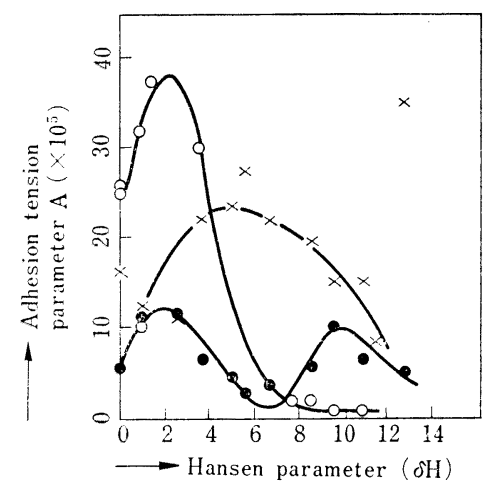

Type A : Mono peak (Titanium dioxide $O$ )

Type B : Broad peak (Insoluble Azo.B $x$ )

Type C: Two peak (Insoluble Azo. A

Fig.-5 Relation between adhesion parameter A and Hansen parameter $\hat{o}_{h}$.

と並んで, 最近は各種の無機物を複合化素材とする熱可 塑性複合プラスチックの研究開発が極めて盛んで一部工 業化されている。この背景には石油資源の節約と新しい 機能の探索がある ${ }^{44), 45) 。}$

古くからゴムに Filler として用いられてきたカーボ ンブラックを除いて, 現在, 広く用いられている無機物 は炭酸カルシウム (重質, 軽質, コロイド状), タルク, カオリン, マイカ, 水酸化アルミニウム, シリカ, ケイ ソウ土, ガラス繊維, カーボン繊維等, その多くは親水 性表面をもっており, 疎水性プラスチックマトリックス に添加した場合，“なじみ”が悪く物性の低下をきたす。 そこで, これら無機物の表面改質が必要となる。

親水性粒子表面の疎水化汇関しては, 古くから顔料な ぞの脂肪酸処理, 界面活性㓮処理等のコーティングによ る改質 ${ }^{46)}$ が実用化されているほか，メカノケミカル反応 による改質 ${ }^{47)}$, カプセル化による改質 ${ }^{48)}$, トポケミカル な改質等, 最近注表面化学的な種々の方法が採用されて いる。

たとえば，シリカゲル（ホワイトカーボン）の表面シ ラノール $(\mathrm{Si}-\mathrm{OH})$ をどニルトリクロロシラン及びトリ メチルモノクロロシラン処理して, 最終的にビニル基と メチル基で抒㧍って表面を有機化したり ${ }^{492}$ ，また，メル カプトシラン処理して, 末端のメルカプト基とゴム分子 とを反応させて三次元的な網目構造をつくらせて, 物性 の向上をはかることが行われている(Fig.-6) ${ }^{50) 。 ~}$

さらに, 最近広く利用され始めたチタナート采カッ プリング剂は下記のような一般構造と機能をもってお $\eta^{511}$, Table-2 に示す各化合物が上市されているが522, これらは分子中に無機物と結合する部分と，有機物に親 和する部分とがあり，無機物にチタナート系カップリン グ剂を添加すると有機物と親和しやすい被膜を形成し, 分散性が著しく改善される。これらの添加剤はますます

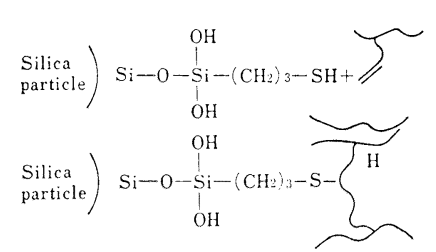

Fig.-6 Filler-Elastomer valcanization coupling.

重要となるであるう。

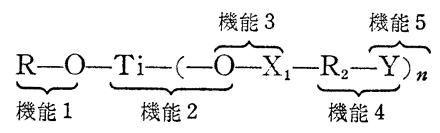

機能 $1:$ 補強, 粘度調節

機能 $2:$ トランスエステル化

機能 $3:$ 安定性

機能 $4:$ 粘度低下, 耐衝撃性

機能 $5:$ 橋かけ

\section{2 溶 解}

\section{$2 \cdot 1$ ミセル溶解}

溶解に関する物理化学的取り扱いは溶液論の方ですで に理論的には,かなり進んでいる。一方, 界面活性剤の溶 解举動についてもすでに多くの研究が行われ, 分子集合 系ミセル，液晶の生成等が知られている ${ }^{53)}$ 。これらのミ セル溶液は, また特異な性質を示し,水系ミセル中に水不 溶性物質を, 非水系ミセル中には水等を溶解することが 可能となる。これらの現象を可溶化 (Solubilization) ${ }^{54)}$ と呼び, 前者はかなり古くから知られている。これら の可溶化系は, 化粰品, 洗浄剂（特にドライクリーニン グ), 食品等に応用され, また, 最近は石油の第三次回 収等において工業的に次第に重要になりつつある。

\section{$2 \cdot 2$ 水系可溶化}

一般に, 水不溶性物質（Solubilizates）を界面活性剤 ミセル水溶液に溶解した可溶化系は乳化と異なり熱力学 的に安定である。可溶化の機棈については

a）ミセル中心溶解型（脂肪族ならびに芳香族炭化水 素をミセル内部の炭化水素部に溶解する場合)

b） パリセード層侵入型（アルコール，脂肪酸，アミ ンなど極性化合物がミセルのパリセード中に侵入 し, 混合ミセルを形成する場合, もっとも大きな可 溶化量を示す)

c）ミセル表面吸着型（極性の強い有機化合物, 染料 等がミセル表面に吸着している場合で,この型の可 溶化は前二者に比較して可溶化量は小さい)

が知られている ${ }^{55)}$

$2 \cdot 2 \cdot 1$ イオン性界面活性剂による可溶化

著者ら ${ }^{56)}$ は, SDS ミセル水溶液中にソルビリゼート としてアルキル炭素数の異なる脂肪族アルコールと脂肪 
Table-2 Titanate coupling agents.

\begin{tabular}{|c|c|c|c|c|c|}
\hline $\begin{array}{l}\text { 「フレンアクト」 } \\
\text { の照程! }\end{array}$ & 化 学: 名 & 化 学 構 噃 & 分于量 & 外 锥 & $\begin{array}{l}\text { 比重 } \\
\left(23^{\circ} \mathrm{C}\right)\end{array}$ \\
\hline $\begin{array}{c}\text { T T S } \\
(2-3099)\end{array}$ & $\begin{array}{l}\text { イソプロピ } \\
\text { トリイソステアロイル } \\
\text { チタナート }\end{array}$ & 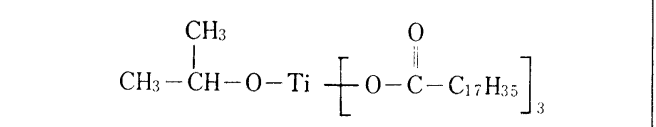 & 957 & $\begin{array}{l}\text { 赤裀低 } \\
\text { 液 }\end{array}$ & 0.94 \\
\hline $9 \mathrm{~S}$ & $\begin{array}{l}\text { イソプロビ } \\
\text { トリドデシルベンゼン } \\
\text { スルホニル } \\
\text { チタナート }\end{array}$ & $\left.\mathrm{CH}_{3}-\stackrel{\mathrm{CH}_{3}}{\mathrm{CH}}-\mathrm{O}-\mathrm{Ti}-\mathrm{O}-\underset{\mathrm{O}}{\mathrm{S}} \longrightarrow-\mathrm{C}_{12} \mathrm{H}_{25}\right]_{3}$ & 1,083 & 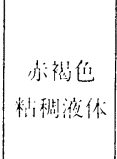 & 1.09 \\
\hline $38 \mathrm{~S}$ & $\begin{array}{l}\text { イソプロビル } \\
\text { トリス(ジオクチルピロ } \\
\text { ホスファート) } \\
\text { チタナート }\end{array}$ & 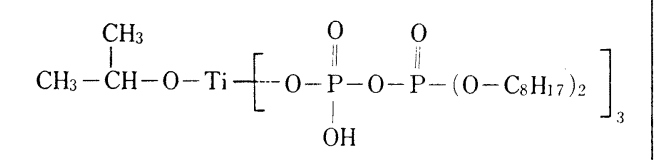 & 1,311 & \begin{tabular}{|c|} 
淡琹赤他 \\
液 体
\end{tabular} & 1.10 \\
\hline $\begin{array}{c}41 \mathrm{~B} \\
\left(\begin{array}{c}7-356 \\
2-1894\end{array}\right)\end{array}$ & $\begin{array}{l}\text { テトライソプロビ } \\
\text { ビス(ジオクチル } \\
\text { ホスファイト) } \\
\text { チタナート }\end{array}$ & $\left.\left[\stackrel{\mathrm{CH}_{3}}{\mathrm{CH}_{3}-\mathrm{CH}-\mathrm{O}}\right]_{4}^{\mathrm{Ti}} \cdot\left[\mathrm{P}-\mathrm{O}-\mathrm{C}_{8} \mathrm{H}_{17}\right)_{2} \mathrm{OH}\right]_{2}$ & 897 & $\begin{array}{l}\text { 淡黄色 } \\
\text { 液 体 }\end{array}$ & 0.97 \\
\hline $\begin{array}{c}46 \mathrm{~B} \\
\left(\begin{array}{c}7-356 \\
2-1894\end{array}\right)\end{array}$ & $\begin{array}{l}\text { テトラオクチル } \\
\text { ビス(ジトリデシル } \\
\text { ホスファイト) } \\
\text { チタナート }\end{array}$ & $\left(\mathrm{C}_{8} \mathrm{H}_{17}-\mathrm{O}+{ }_{4} \mathrm{Ti} \cdot\left[\mathrm{P}-\mathrm{O}-\mathrm{C}_{33} \mathrm{H}_{27}\right)_{2} \mathrm{OH}\right]_{2}$ & 1,458 & $\begin{array}{l}\text { 淡烡延 } \\
\text { 液 休 }\end{array}$ & 0.94 \\
\hline 55 & $\begin{array}{l}\text { テトラ(2,2-シアリルオキシ } \\
\text { ×チルー1ープチル) } \\
\text { ヒス(シートリデル) } \\
\text { ホスファイト } \\
\text { チタナート } \\
\end{array}$ & {$\left[\mathrm{C}_{2} \mathrm{H}_{5}-\mathrm{C}-\mathrm{CH}_{2}-\mathrm{O} \longrightarrow\right]_{4} \mathrm{CH} \cdot\left[\mathrm{P}-\left(\mathrm{O}-\mathrm{C}_{13} \mathrm{H}_{27}\right)_{2} \mathrm{OH}\right]_{2}$} & 1,794 & $\begin{array}{l}\text { 薄 仙 } \\
\text { 液 体 }\end{array}$ & 0.97 \\
\hline $138 \mathrm{~S}$ & $\begin{array}{l}\text { ビス(ジオクチル } \\
\text { ピロホスファート) } \\
\text { オキシアセタート } \\
\text { チタナート }\end{array}$ & 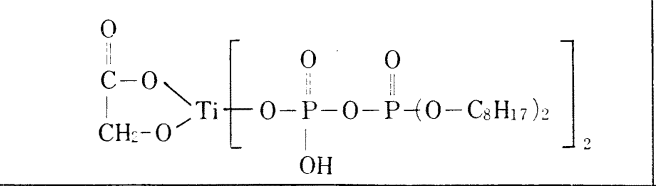 & 925 & $\begin{array}{l}\text { 淡渭色 } \\
\text { 液 休 }\end{array}$ & 1.09 \\
\hline $238 \mathrm{~S}$ & $\begin{array}{l}\text { トイ(ジオクチル } \\
\text { ピロホスファート) } \\
\text { エチレン } \\
\text { チタナート }\end{array}$ & $\left.\mathrm{CH}_{2}-\mathrm{O}>\mathrm{Ti}-\mathrm{C}-\begin{array}{c}\mathrm{O} \\
\mathrm{O}-\mathrm{O}-\mathrm{O}-\mathrm{P}-\left(\mathrm{O}-\mathrm{C}_{8} \mathrm{H}_{17}\right)_{2} \\
\mathrm{OH}\end{array}\right]_{2}$ & 911 & $\begin{array}{l}\text { 淡蓝色 } \\
\text { 液 休 }\end{array}$ & 1.08 \\
\hline
\end{tabular}

酸を用いた実験を行い, 可溶化量は油性物質分子の炭素 数の増加にともなって減少し, また, 同じ炭素数の場合 脂肪酸の方がアルコールよりも可溶化量が大きくなるこ とを見いだしている。

水に不溶性物質を溶解するには界面活性剤ミセル中に 可溶化させるわけであるから, 用いる界面活性剤は cmc の低いものほど効果的である。したがって, 界面活性剤 が同族の場合, アルキル基を長くするほど cmc は小さ
くなるので油の可溶化量は多くなる ${ }^{57) 。 こ れ は, ~ ソ ル ヒ ゙ ~}$ リゼートが極性, 無極性, また, 脂肪族, 芳香族にかぎ らずそそららことがいえる。しかしながら，イオン性 界面活性剂の場合, アルキル鎖長が大きくなるにつれて Krafft 点が上昇し 58),59), 実用から遠ざかる。そのため に親油基と親水基との間に，エチレンオキシドやプロピ レンオキシドを導入したアルキルエーテル硫酸塩(0), 61) やアルキルエーテルカルボン酸塩 ${ }^{62)}$ などが用いられる。 
また，アルキル基に分枝をもたせることにより $\mathrm{Krafft}$ 点を低下させ，低温における可溶化が可能となる。しか も分枝アルキル系の方が可溶化量が多いことも見いださ れている(3),64)。

イオン性界面活性剤の場合, 電解質の添加によって $\mathrm{cmc}$ が小さくなるので, 可溶化量が增すことが知られて いる(5) 67)。一方, 非電解質に関しては, ペンタノールや オクタノールを co-solubilized additives として添加 することによりイオン性界面活性鼡水溶液一の可溶化量 が影響されることが明らかにされている65。

\section{$2 \cdot 2 \cdot 2$ 非イオン性界面活性剤による可溶化}

一般に, 非イオン界面活性㶡の cmc はアニオン系界 面活性剤のそれより1オーダー低い, したがって, 非イ オン界面活性剂水溶液中への油の可溶化能はアニオン系 界面活性剤系より大きい(68),69)。しかし温度の影響を受 けやすく, 显り点で界面活性剤と水とが分離してしまう 欠点がある ${ }^{66)}$ 。非イオン界面活性剤水溶液中への油の可 溶化量はある温度籁囲で急激に増加すること, 塩添加, 界 面活性剤の親水基であるオキシエチレン鎖長, 及び親油 基であるアルキル基に依存することが知られている ${ }^{70) 。 ~}$

最近, 非イオン界面活性剤水溶液への油の可溶化に対 する多価アルコールの添加効果が報告されている ${ }^{11}$ 。そ れによるとポリオキシエチレンオレイルエーテル $\mathrm{POE}$ $(n=10) 3 \mathrm{wt} \%$ 水溶液の水の一部を Dーソルビトール, グリセリンで置換することによって流動パラフィンの可 溶化量が増大することが見いだされている。

$2 \cdot 2 \cdot 3$ 水系における界面活性坟混合系による可溶化 の向上

親水性の強いイオン性界面活性剤水溶液に親油性の強 い非イオン性界面活性剤を加えると，ミセルの会合数が 増し, イオン性/非イオン界面活性剤のある比率で溶液 は濁り始める。これは界面活性剤相または液晶相がミセ ル溶液から分離するためで, 混合することにより界面活 性剂の親油性一親水性のバランスが変わるためである。 このようにイオン性界面活性剤と非イオン性界面活性剤 を混合し，適当な HLB にすると可溶化能を著しく向 上することができる。たとえば，Fig.-7 に示すように， 親水性の強い $\mathrm{C}_{8} \mathrm{H}_{17} \mathrm{CH}\left(\mathrm{C}_{6} \mathrm{H}_{13}\right) \mathrm{COONa}$ 単独だと, シク ロヘキサンの可溶化量は $2.6 \mathrm{~g} / 100 \mathrm{~g}$ aq. soln. である が, これに親油性の強い $\mathrm{C}_{8} \mathrm{H}_{17} \mathrm{O}\left(\mathrm{CH}_{2} \mathrm{CH}_{2} \mathrm{O}\right)_{2} \mathrm{H}$ が併用 されると可溶化量は増加し, 最大で $13.4 \mathrm{~g} / 100 \mathrm{~g}$ aq. soln. までに達する ${ }^{72}$ 。

\section{$2 \cdot 3$ 非水系可溶化}

非水溶液中におけけるミセル形成は, 界面活性剂のア ルキル基部を外側に，極性基部を内側にした，いわゆる 逆(型)ミセルとなるが, 水溶液系のように $\mathrm{cmc}$ がはっ きりしない場合もあり， cmc が明確に存在するかどうか についても議論の対象になっている。そして仮に $\mathrm{cmc}$

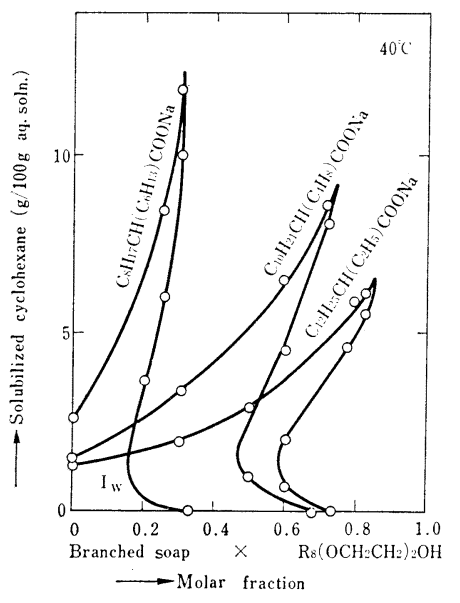

Fig.-7 The solubilized region $\left(I_{w}\right)$ of cyclohe= xane in $0.164 \mathrm{~mol} / \mathrm{kg}$ aqueous micellar solutions of the mixture of branched soaps with $\mathrm{C}_{8} \mathrm{H}_{17}\left(\mathrm{OCH}_{2} \mathrm{CH}_{2}\right)_{2} \mathrm{OH}$. The solubilized region in L.C. in not deter= mined.

と見られる濃度以上においても, その会合数は非水溶媒 によって異なるが, 数分子ないし十数分子というくらい でミセルと呼べるかどうか疑問の点がある ${ }^{73}$ 。また, cmc の值も $10^{-2} \mathrm{M}$ で水中の場合の $10^{-3} \sim 10^{-4} \mathrm{M}$ より 1オーダー大きい。しかし, 被可溶化物である水の添加 によって, はっきりしたミセルが形成され, 可溶化が進 むことが知られている ${ }^{74), 75) 。 ~}$

$2 \cdot 3 \cdot 1$ 非水系におけるイオン性界面活性剤による可 溶化

イオン性界面活性剤は一般に親水性が強いため単独で はあまりよい可溶化凨とはならない。そこで, cosurfac= tant や塩を加えて 界面活性㓮の HLB をつり合わせる 試みが行われている ${ }^{76)}$ 。

しかし，2 個のアルキル基鎖をもつ Aerosol OT は イオン性界面活性剤にもかかわらず非水溶媒にもよく溶 解し, 多量の水を可溶化することができる77) 79)。また, 水和した界面活性剤の融点である $\mathrm{Krafft}$ 点も二鎖型の 方が低いことより実用的であるといえる。特に, 二鎖型

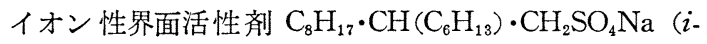
$\mathrm{R}_{16} \mathrm{SO}_{4} \mathrm{Na}$ と略す) は $\mathrm{HLB}$ のつり合いが良いため cosurfactant を必要とせず, 塩の添加のみで HLB をつり 合わせることができると報告されている(76) 80)。2つの アルキル基鎖をもつものはカチオン系 ${ }^{81}$ や非イオン系界 面活性剤でも親油性が強く非水溶媒によく溶解する ${ }^{82}$ 。

$2 \cdot 3 \cdot 2$ 非水系における非イオン界面活性剂による可 溶化

非イオン界面活性剂の非水溶液による水の可溶化につ いても水系と同様, 温度に依存し, ある狭い温度範囲で 最大可溶化量が得られることが知られている ${ }^{83), 84) 。 そ ~}$ 
してその最適温度（水飽和曇り点と呼ばれる）及び最大 可溶化量は界面活性剤の構造, 非水溶媒の種類 ${ }^{85)}$ ，なら びに塩類添加 ${ }^{83)}$ などに大きく依存する。

アルキルフェニルニポリオキシエチレン=エーテル系非 イオン界面活性剤の親油基部分（アルキルフェニル， $\left.\mathrm{Rm}-\mathrm{C}_{6} \mathrm{H}_{4} \mathrm{O}-\right)$ ， と親水基部分 [ポリオキシェチレン， $\left.\left(\mathrm{CH}_{2} \cdot \mathrm{CH}_{2} \mathrm{O}\right)_{n}{ }^{-}\right]$との大きさを変えて, $5 \mathrm{wt} \%$ シクロ ヘキサン溶液中への水の可溶化量の温度変化から水飽和 昙り点と最大可溶化量を求めた結果が Fig.-8 亿示され ている ${ }^{84)}$ これより,親油基部分と親水基部分とがともに ある程度大きい界面活性剤が有効であることがわかる。

非イオン界面活性冎でも 2 つのアルキル基をもつもの は親油性が強くなり, より非水溶媒汇溶解しやすくな $る^{81)}$ 。

非イオン界面活性剤同士の混合効果についてみると, より親水性の強いものを混合すると水飽和量り点が高温 側に移行し，逆に親油性の強い界面活性剤を添加すると 水飽和晴り点が低温側に移行し, 水最大可溶化量は増加 する傾向が明らかになっている。前者の例に, $\mathrm{NPE}_{7.4}$ とスクロースミリスタート (SM) 系が, 後者の例に, $\mathrm{NPE}_{7.4}$ と Span 20 采及び $\mathrm{NPE}_{\bar{n}}$ 系列の $\bar{n}$ を短くし た場合の例があげられる ${ }^{84}$ 。

$2 \cdot 3 \cdot 3$ 非水系に抢汀る界面活性剤混合系による可溶 化の向上

非水系における混合界面活性剂による水の可溶化につ いては、ドライクリーニング溶媒として最も多く用いら れている四塩化エチレンを溶媒としてアニオンと非イオ ン界面活性剂，カチオンと非イオン界面活性剂の混合非 水溶液にお汀る水の可溶化の温度依存性が調心゙られてい る ${ }^{86)}$ 。すなわち，アニオン界面活性剤として Aerosol

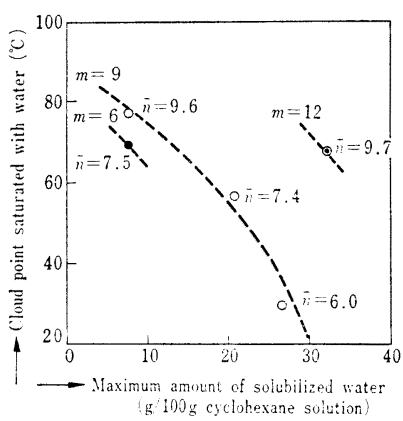

Fig.-8 Effects of the hydrophilic and lipophilic chain length of $\mathrm{R}_{m} \mathrm{C}_{\hat{0}} \mathrm{H}_{4} \mathrm{O}\left(\mathrm{CH}_{2} \mathrm{CH}_{2}\right)_{\bar{n}} \mathrm{H}$ on the cloud point satura $=$ ted with water and the maximum amount of solu= bilized water. [Concentra $=$ tion of $\mathrm{R}_{m} \mathrm{C}_{3} \mathrm{H}_{4} \mathrm{O}\left(\mathrm{CH}_{2}=\right.$ $\left.\mathrm{CH}_{0} \mathrm{O}\right)_{\bar{n}} \mathrm{H}: 5 \mathrm{wt} \%$ (10 $\mathrm{wt}^{*}$.]
OT，カチオン界面活性剤としてブチルドデシルジメチ ルアンモニウムニブロミド (BDAB), 非イオン界面活性 珮としてノニルフェニルニポリオキシエチレンニエーテル (平均 オキシエチレン基数 $n=4,6,8,10)(\mathrm{NP}=4,6$, $8,10)$, ソルビタンモノオレアート $(\mathrm{SMO})$, グリセリン モノオレアート $(\mathrm{GMO})$ を用いて，それぞれの混合系 について検討されている。

アニオンと非イオン界面活性剤混合系では，たとえば Aerosol OT : NP の混合比が 1: 3 になると, 高温領域 に円形の白濁領域が現れ可溶化領域は減少するが，低温 領域では可溶化領域が著しく広がる。たとえば, $30^{\circ} \mathrm{C} の$ 一定温度で混合溶液による可溶化量は，それぞれ単独の 界面活性剤による可溶化量の和より 3 倍以上増加するこ とが見いだされている。

カチオンと非イオン界面活性剂混合溶液系では, BD $\mathrm{AB}$ と $\mathrm{NP}=8, \mathrm{GMO}$ 及び $\mathrm{SMO}$ との混合溶液につい て調べられているが, $\mathrm{BDAB}$ と $\mathrm{SMO}(1: 1)$ 系の水の 可溶化量は測定温度範囲すべてにわたって増加した。特 に $50^{\circ} \mathrm{C}$ 付近で水の可溶化領域が急激に広がり，それぞ れの界面活性㓮による可溶化量の和より 14 倍も增加し, 相乗効果が認为られている (Fig.-9)。

\section{$2 \cdot 4$ ミクロエマルション}

すでに述べてきたように界面活性剤溶液にある種の極 性物質を添加することによりエマルションを安定化した り，可溶化能を增大させることを知った。Schulmann ら 泣, イオン性界面活性郕/水/油系のエマルションに $\mathrm{C}_{4-5}$ 以上の長鎖アルコールを添加することにより，水，油を 多量に含む透明な溶液を得て，これをミクロエマルショ ン (microemulsion) と名づ行 ${ }^{87) ~ 899}$ 。ミクロエマルシ ヨンは外観が青色透明の状態で，エマルション系なのか 可溶化系なのか議論が分かれてきたが，その後，Fri berg ${ }^{90)}$ や篠田 ${ }^{917,92)}$ の相平衡図による検討からミク ロエマルションが多量の油（または水）を可溶化し, 膨 潤したミセル水溶液（また注ミセル油溶液）であること を明らかにした。したがって，可溶化量を增すには，ミ クロエマルションの利用が有効である。

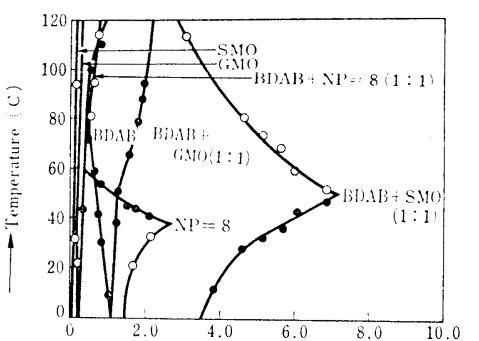

-Arnourt of water iddded ( 100 or solution

Fig.-9 Solubilization of water by cationic and nonionic sur $=$ factants in tetrachloroethy= lene solutions. この場合, 界面活性剂濃庴注 $\mathrm{cmc}$ 上り 充分高く（たとえば $5 \mathrm{wt} \%$ ），すでに可 溶化の項でも述べられている。

ミクロエマルションの生成について， イオン性界面活性剂/水/油系において は，イオン性界面活性凧の強い親水性を 抑えるため混合ミセルを形成する長鎖厂 ルコール等のいわ泌る co-surfactant を加えたり ${ }^{75,937}$ ，塩析効果のある無機 塩などを加えて HLB を適当にするこ とが必要である ${ }^{949}$ 。の場合, co-sur= factant はエチレンオキシドの付加モル 
数の少ない非イオン界面活性剤であってもよい ${ }^{95}$ 。一 方, 非イオン界面活性剤系については，非イオン界面活 性剤/水/油系の温度調節，エチレンオキシド鎖長の調節 などを行ってミクロエマルションを生成する条件を非ぶ ことが重要となる ${ }^{96)}$ 。

以上, 水系, 非水系の可溶化について簡単に述べてき たが，国枝ら ${ }^{91}$ は，水と油の相溶性を相平衡図を用いて 研究し，なるべく少量の界面活性剤で可溶化量を堌大さ せる条件として次のことを提唱している。

1）単一または混合界面活性剤の HLB（すなおち PIT)が適度なこと。

2) 非イオン性界面活性刜に関しては適度な温度 (PIT 付近) を選ぶこと。

3）混合界面活性剤の場合は HLB（または PIT）が 適度となるよう混合すること。

4） 2 種の界面活性剤を混合して用いるときは両者の HLB がたがいに近いことが望ましいこと。

5) もし HLB が近いならイオン性界面活性剂と非 イオン性界面活性剤の混合がよいこと。

6）同じ HLB（または PIT）のものでは親油基，親 水基の大きい方が界面活性㓮濃度はより低濃度でよ いこと。

\section{$2 \cdot 5$ その他の溶解剂}

\section{$2 \cdot 5 \cdot 1$ Hydrotrope}

以上述べてきた界面活性剤の可溶化效果に対し，水不 浴性のニトロベンゼン, 酢酸エチル, ベンジルアルコー ル，レシチン及びその誘導体などの有機物を水に溶解さ せるものに“ヒドロトロープ” (Hydrotrope) と呼ばれる ものがある ${ }^{96) \sim 98)}$ ここれらに属するものとしては，ベン ゼン, トルエン等のスルホン酸塩のほか, 脂肪族, 芳香 族ならびにアルキル環状化合物のカルボン酸塩等が含ま れ，比皎的低分子量の有機化合物で，分子中に親水基と 親油基をもち，他の有機化合物を水あるいは塩類の水溶 液中に高濃度に溶か寸性質をもっている。これらは分子 構造のうえからは界面活性剤に類似しているが，アルキ ル基が短く，たとえば， lower alkylbenzene sulfonate のようなむので, この分子に多数の水分子が会合して一 つの新しい溶媒ができるものと見なされる。この場合， sulfonate と水とのモル比は一般の無機塩と大体同じ程 度の大きさと見られ，一方，ヒドロトロープと被溶解物 質とは分子性付加物 (molecular adducts) を形成して 溶解性が買加すると見られている ${ }^{99), 10 引 。 ~}$

代表的なヒドロトロープとしては，次のようなものが あり，その溶解性は温度により影響されるが，

クメンスルホナート>エチルベンゼンスルホナートモ トルエンスルホナート>m-キシレンスルホナート >ベ ンゼンスルホナートミo-キシレンスルホナート>p-キ シレンスルホナート
の覑である。

これらは被溶解物質ならびに塩類溶液の違いによって 若干異なるが，イオン性界面活性剤などを高濃度にビル ダー溶液に溶解してつくられるへビー・デューティ液体 洗剤のような場合 ${ }^{101)}$, ヒドロトロープ 分子の構造とし ては側鎖の炭素数や分枝状態によって左右されるが，大 体, 炭素数 9 個 $\left(\mathrm{C}_{9}\right)$ 位のところに落ち着くことが見いだ されている。炭素数があまり大きくなるとヒドロトロー プ自身の溶解度が減少して本来の目的に沿わなくなる。

その他，以わゆる可溶化剂としては，水の水素結合を 断ち切って有機化合物を溶解しやすくする効果のあるも のとして，尿素，チ才尿素などの尿素誘導体がある。

\section{$2 \cdot 5 \cdot 2$ その他の溶解剂}

その他の溶解剂として各種の無極性, 極性の異なる有 機溶媒があり，前者には脂肪族，芳香族，環状化合物が 含まれ，後者にはアルコール，エーテル，ケトン，エス テル，アミン，複素環化合物その他多くの有機化合物が あり，それらは前述した溶解性パラメーター成分も明ら かにされている。そして, 溶解に関して多くの理論的, 実験的研究がなされており，その中には “混合の妙” と いわれるものも数多くあるが，それは別の機会に譲る。 (昭和 59 年 7 月 26 日受理)

\section{文献}

1）伊勢村寿三，化学の研究，9，159 (1951)

2）荻野圭三，太田基已，油化学，23，28（1974）

3) K. Ogino, H. Umetsu, Bull. Chem. Soc. Jpn., 51, 1543 (1978)

4）米山雄二，荻野圭三. 油化学，32，43 (1983)

5) K. Ogino, M. Ota, Bull. Chem. Soc. Jpn., 49, 1187 (1976)

6）岡本国雄，大石秀夫，薬学誌，97，251 (1977)

7) K. Ogihara, M. Ueno, K. Meguro, Yukagaku, 31, 146 (1981)

8) K. Shinoda, H. Saito, J. Colloid Interface Sci., 30, 270 (1969)

9) K. Shinoda, H. Saito, H. Arai, J. Colloid Interface Sci., 35, 624 (1971)

10) K. Shinoda, H. Arai, J. Phys. Chem., 68, 3485 (1964)

11) K. Shinoda, J. Colloid. Interface. Sci., 24, 4 (1967)

12) 公開特許 昭 56-144,732 (1981)

13）蕗谷広道, 竹/内正紀, 油化学, 30, 38 (1981)

14) H. Sagitani, J. Am. Oil Chem. Soc., 58, 738 (1981)

15）跽谷広道, 服部孝雄, 鍋田一男, 永井昌義, 日化, 1983, 1399

16) S. Saito, Kolloid Z., 133, 12 (1953), 137, 93 (1954)

17) U.P. Stranss, E.G. Jackson, J. Polymer Sci., 6, 649 (1951)

18）立松良一，長瀬俊治，犬飼 鑑，油化学，33，46 (1984)

19）熊野可丸, 中村 新, 田原定明, 公開特許 53-129,185 (1978)

20）谷口承雄，公開特許， $56-147,622$ (1981)

21）蕗谷広道, 篠田耕三, 油化学, 24, 171 (1975)

22) K. Shinoda, H. Sagitani, J. Colloid. Interface Sci., 64, 68 (1978)

23）路谷広道, 晹浅正治, 油化学, 26, 240 (1977) 
24) E.W.J. Verway, J. Th. G. Overbeek, "Theory of the stability of Lyophobic Colloids" Elsevier Pub. Co. New York (1948)

25）北原文雄, 渡辺 昌編 “界面電気現象” (共立出版) (1978)

26) A. Watanabe, Bull. Inst. Chem. Research Kyoto University (1960)

27) J.C. Harris, J.R. Van Wazer, "Phosphorus and Its Compounds" Interscience Publishes, Inc. (1961)

28) B. Tamamushi, K. Tamaki, "Surface Activity Proceed= ing of 2nd Intern Congress, London (1957)

29) H.P. Boehm. Angerw. Chem. Int. Ed., 5, 533 (1966)

30) M.L. Corrin, E.L. Lind, A. Roginsky, W.D. Harkins, J. Colloid Sci., 4, 485 (1949)

31）安部郁夫, 林 勝已, 北川㓐夫, 油化学, 25, 145 (1976), 26, 355 (1977)

32）浅川丈夫, 荻野圭三, 第36回コロイドなよび界面化学討 論会発表 (1983.10.9)

33）北 龍二，木暮郁雄，色材，53，299 (1980)

34) F. Tokiwa, T. Imamura, J. Am. Oil Chem. Soc., 46, 571 (1968)

35）竹内 節, 常盤文克, 谷野幸雄, 服部健一, 工. 化, 74, 2239 (1971)

36）青木由郎，色材， 51，651（1978）

37）石上裕，鈴木 茂，山䗁信助，鈴木 洋，色材， 54 , 671 (1981)

38）荻原公彦, 富岡真幸, 江角邦男, 目黑謙次郎, 色材, 54, 546 (1982)

39) B.R. Vijayendran, ACS Symposium Series, 9, "Col= loidal Dispersions and Micellar Behavior", 211 (1975)

40) R. Abe, H, Kuno, Kolloid-Z, 181, 70 (1962)

41) W. Black, F.H. Hesselink, T. Topham, Kolloid-Z. u. Z. polymers., 213, 150 (1966)

42) 藤谷俊英, 佐藤忠明, 色材, 55, 459 (1982)

43) C.M. Hansen, K. Shaarup, J. Paint Tech., 39, 511 (1967)

44) 由茾 浩, Plastic Age, 105 (1979)

45）高橋 浩, 生座研究, 33, 255 (1981)

46) A.F. Sherwod, S.M. Rybieka, J. Oil Colour Chem. Assoc., 49, 648 (1966)

47）高橋 浩, 生産研究, 26, 490 (1974)

48) H.G. Dekking, J. Appl. Polymer Sci., 9, 1641 (1965) 11, 23 (1967)

49) A.A. Cujks et al., Kollid Z.,31, 779 (1969)

50) E.M. Dannenberg et al., Colloq. Intern. du C.N.R.S. No. 231 (1975)

51）寺田 裕, 高分子, 26, 695 (1977)

52) チタネートカップリング剤（味の素技術資料）

53）北原文雄方, “界面活性剂”講談社 (1979) p. 69

54) J.W. McBain, M.E.L. McBain, J. Am. Chem. Soc., 58, 2610 (1936)

55) J.W. McBain, H. McHan, J. Am. Chem. Soc., 70, 3838 (1948)

56) K. Ogino, M. Abe, N. Takeshita, Bull. Chem. Soc. Jpn., 49, 3679 (1976); 51, 1880 (1978); 53, 611 (1980)

57) P.H. Elworthy, C.B. Macfarlane, J. Chem. Soc., 1963 907

58) K. Shinoda, T. Soda, J. Phys. Chem., 67, 2072 (1963)

59) K. Ogino, Y. Ichikawa, Bull. Chem. Soc. Jpn., 49, $2683(1976)$

60) M. Hato, M, Tahara, Y. Suda, J. Colloid Interface Sci., 72, 458 (1979)

61) 辻井 薰, 岡橋憲司, 竹内 節, 油化学, 30, 566 (1981)
62）荻野圭三，阿地孝則，田端勇仁，日化，1980，1385

63) H. Sagitani, T. Suzuki, M. Nagai, K. Shinoda, $J$. Colloid Interface Sci., 87, 11 (1982)

64) K. Shinoda, H. Sagitani, J. Phys. Chem., 87, 2018 (1983)

65) H.B. Kelevens. J. Am. Chem. Soc., 72, 3780 (1950)

66) H. Saito, K. Shinoda, J. Colloid Interface Sci.,24, 10 (1967)

67) K. Shinoda, H. Takeda, J. Colloid Interface Sci,. 32, 642 (1976)

68) H.B. Kelevens, Chem. Rev., 47, 1 (1950)

69) K. Shinoda, "Solvent Properties of Surfactant Solutions" Marcel Dekker N.Y., (1967) p. 51

70）今野紀二郎，北原文雄，油化学，22，335（1973）

71）路谷広道, 池田由美子, 大郷保治, 油化学, 33, 156 (1984)

72) H. Sagitani, T. Suzuki, M. Nagai, K. Shinoda, J. Colloid. Interface Sci., 87, 11 (1982)

73) K. Shinoda, "Colloid Surfactants" Academic Press. N. Y. (1963) p. 1

74) A. Kitahara, J. Phys. Chem., 69, 2788 (1965)

75) E. Sjoblom. S. Friberg, J. Colloid Interface Sci., 67, 16 (1978)

76）柴田 裕，篠田耕三，第 49 回日本化学会秦季年会発表 (1984.4.1)

77) K. Konno, A. Kitahara, J. Colloid Interface Sci, 37, 469 (1971)

78) H.F. Eicke, P.E. Zinshi, J. Colloid Interface Sci., 65, 131 (1978)

79) H. Kunieda, K. Shinoda., J. Colloid Interface Sci., 70, 577 (1979)

80）国枝博信，日化，1977，151

81) H. Kunieda, K. Shinoda, J. Phys. Chem., 82, 1710 (1978)

82) 高橋秀男, 大螎秀明, 桑村常彦, 油化学, 24, 43 (1975)

83) K. Konno, A. Kitahara, J. Colloid Interface Sci., 34, 221 (1970)

84）斉藤 博, 日化, 1972, 491

85) K. Shinoda, T. Ogawa, J. Colloid. Interface Sci., 24, 56 (1967)

86）今野紀二郎, 松山隆夫, 北原文雄, 油化学, 23, 571 (1974)

87) J.H. Schulman, D.P. Riley, J. Colloid Sci., 3, 383 (1948)

88) J.H. Schulman, J.A. Friend. J. Colloid Sci., 4, 497 (1949)

89) J.E. Bowcott, J.H. Schulman, Z. Electrochem., 59, 283 (1955)

90) S, Friberg. J. Am. Oil Chem. Soc., 48, 578 (1971)

91）国枝博信，篠田耕三，日化，1972，2001

92) K. Shinoda, S. Friberg. Advance Colloid Interface Sci., 4, 281 (1975)

93) D.O. Shab, R.M. Hamlin, Science, 171, 483 (1971)

94) H.F. Eicke, H. Christen, J. Colloid Interface Sci., 46, 417 (1974); 48, 281 (1974)

95) H. Sagitani, S.E. Friberg, J. Dispersion Sci., Tech= nol., 1, 151 (1980)

96) C. Neuberg, Biochem, Z., 76, 107 (1916)

97) C. Neuberg, H.A. Fischer, Rec. Trav. Chim., 59, 77 (1940)

98) C.D. Moor, M. Bell. Am. Perfumer, \& Cosmetics. June. 25 (1959)

99) R.L. Huddleston, E.A. Setzkom, Soap \& Chem. Spe= ciality, 3, 63 (1965)

100）荻野圭三，化学市場研究資料 67-6 (1967)

101) M. Mausner, P. Sosis, Soap \& Chem. Speciality, 2, 47 (1962) 